\title{
Solid-state Dewetting Formation of In/InTe Nanosystem
}

\author{
P.V. Galiy,1,*, T.M. Nenchuk1, A. Ciszewski², P. Mazur², O.V. Tsvetkova1, V.I. Dzyuba1, T.R. Makar ${ }^{1}$ \\ ${ }^{1}$ Ivan Franko Lviv National University, 50 Dragomanov St., 79005 Lviv, Ukraine \\ ${ }_{2}^{2}$ Institute of Experimental Physics, University of Wroclaw, 9, pl. Maxa Borna, 50-204 Wroclaw, Poland
}

(Received 25 June 2021; revised manuscript received 10 August 2021; published online 20 August 2021)

\begin{abstract}
Solid-state dewetting (SSD) method as a promising way to obtain nanostructures was applied for the formation of $\mathrm{In} / \mathrm{InTe}$ nanosystem. The phase-elemental composition and structural perfection of the initial InTe surface were characterized by X-ray photoelectron spectroscopy, low energy electron diffraction (LEED) and atomic force microscopy (AFM). X-ray diffraction (XRD) studies revealed the InTe tetragonal crystal structure of the TlSe type (I4/mcm space group, lattice parameters $a=8.4414(6) \AA, c=7.1333(5) \AA)$. Scanning tunneling microscopy (STM) studies of the initial InTe (001) surface and the same one used as an ordered template after thermal indium deposition showed that the shape and arrangement of indiuminduced nanostructures are powered by square surface lattice symmetry as derived from a tetragonal InTe bulk one. We observed the formation of nanosized OD structures as a result of the SSD process due to surface heating above the indium melting point. The scanning tunnelling spectroscopy (STS) revealed correlation between indium coverage kinetics and an increase in the amount of density of states (DOS) at the surface within the band gap of InTe.
\end{abstract}

Keywords: Layered chalcogenides, Self-assembling nanostructures, Solid-state dewetting, Scanning tunneling microscopy/spectroscopy, Atomic force microscopy, X-ray photoelectron spectroscopy, Low energy electron diffraction.

DOI: 10.21272/jnep.13(4).04032

\section{INTRODUCTION}

The InTe monocrystal surface has not been studied well enough, but, like other 2D layered chalcogenide semiconductors, e.g., recently appeared InSe [1, 2], may now be of interest for application in functional nanoscale devices. Data on the crystal structure of InTe from the indium-tellurium system have been known for a long time [3]. Structural, chemical, thermal and vibrational studies of InTe crystal [4], InTe films grown on glass substrates [5] looking forward for potential applications in photodetectors and solar cells were conducted. Interesting, in terms of surface properties of InTe, are the studies of nickel-indium telluride Schottky barriers prepared by sequential evaporation and their electrical characteristics. Herewith various diode parameters are reported [6].

The results on topology and structure of oxidized and unoxidized surfaces of InTe layered crystal using atomic force microscopy (AFM) in air and X-ray phase analysis are presented [7]. However, at present, there is still a lack of experimental results to analyze possibilities of InTe cleavage surfaces application, especially, obtained in UHV and studied by scanning probe microscopy methods in situ.

In this paper, we continue the analysis of the use of cleavage surfaces of layered indium chalcogenides, as perfect templates, for the formation of metal nanostructures using the solid-state dewetting (SSD) phenomenon after metal's thermal deposition. Incidentally, SSD method has been extensively investigated in the past decades [8-10]. Previously, we reported on In/(100) $\mathrm{In}_{4} \mathrm{Se} 3$ [11] and In/InSe (0001) [12] nanosystems formation.
PACS numbers: 68.37.Ef, 68.37.Ps, 68.47.De, 68.47.Fg, 73.20.At, 68.35.bg, 81.65.Cf, 79.60. - i
Due to InTe intrinsic bulk anisotropy, its (001) surface can be easily obtained by cleavage even in UHV which makes it suitable as a template for obtaining nanosystems with reduced dimension with application of SSD in situ. In consequence of our studies, it should be noted that SSD method application combined with natural patterned surface topography of $2 \mathrm{D}$ layered crystals and their surfaces' poor adhesion are one among the most perspective routes to self-assembling of metal nanostructures in producing arrays of nanoscale shapes for electronic and photonic devices and for catalyzing growth of nanodots, nanotubes and nanowires.

\section{DESCRIPTION OF OBJECTS AND INVESTIGATION METHODS}

InTe layered semiconductor crystals were grown by the Bridgman-Stockbarger method from previously synthesized In-Te melts, which have a homogeneous structure. The initial surface before deposition, the socalled template, was characterized by X-ray photoelectron spectroscopy (XPS) (Fig. 1a) and low energy electron diffraction (LEED) (Fig. 1c).

Fig. 1b shows data of X-ray Powder Diffraction (XRD) studies (STOE STADI P, CuKa1) of the grown crystals with a bulk tetragonal crystal structure of the TlSe type (I4/mcm space group, lattice parameters $a=8.4414(6) \AA$ and $c=7.1333(5) \AA)$. The templates have got phase-elemental composition of InTe as determined by XPS and excellent surface structural quality in macroscale according to LEED. XPS and LEED data were acquired by SPECS Surface Nano Analysis $\mathrm{GmbH}$.

Fig. 1a shows the XPS spectrum with the main reference peaks of the InTe components (In 3d5/2, Te

\footnotetext{
*nenchuk@electronics.lnu.edu.ua
} 
3d5/2). XPS spectra also reveal low intensity peaks of carbon $\mathrm{C} 1 s$ and oxygen $\mathrm{O} 1 s$. The latter are due to the adsorption of atmospheric components on the surface of InTe sample studied after cleavage ex situ. Quantitative XPS analysis determined that the relative concentration of the In and Te main components corresponds

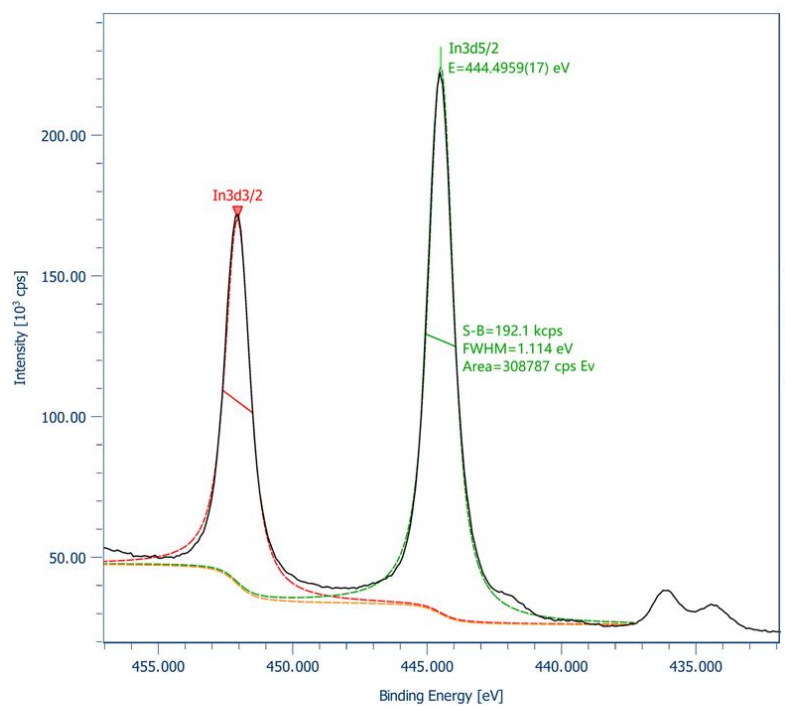

$\mathrm{b}$

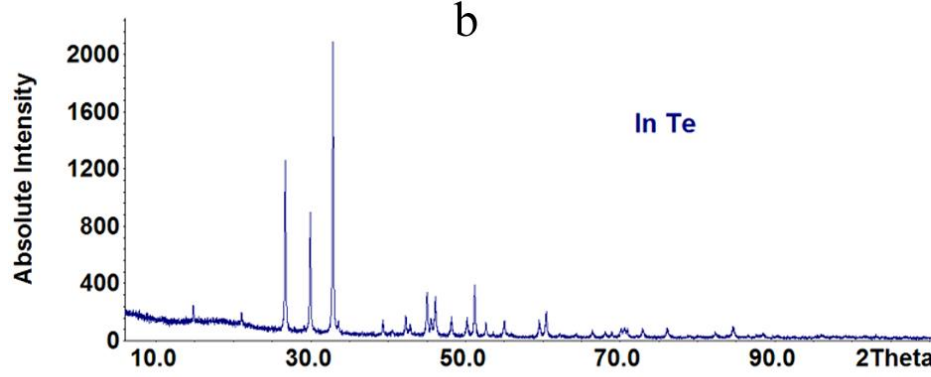

to the surface stoichiometry of the InTe compound (indium $-50.27 \%$, tellurium $-49.73 \%$ ).

Fig. 1c shows the LEED pattern of the as-cleaved sample of InTe obtained by ErLEED 100 optics at a primary electron energy of $58 \mathrm{eV}$ with spots arranged in a tetragonal manner.
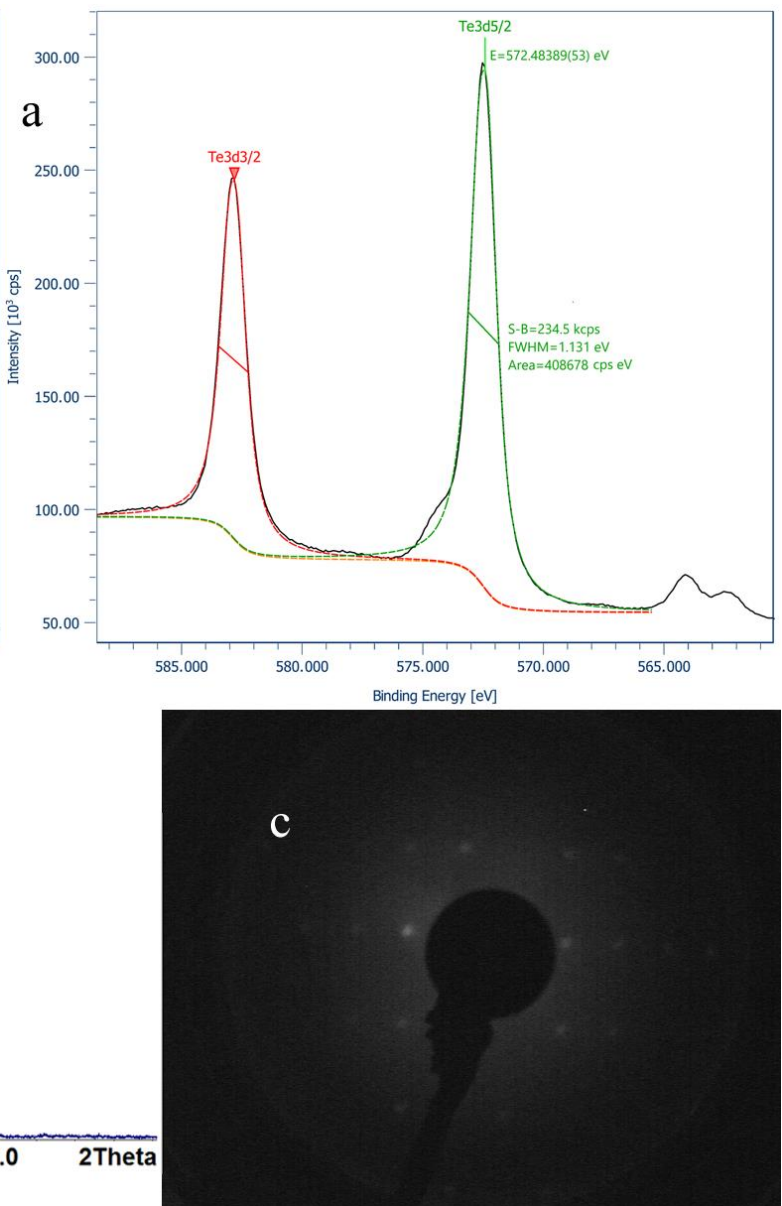

Fig. 1 - InTe crystal bulk characterization by: a) XPS peaks of indium and tellurium acquired from initial InTe surface, b) results of XRD study (STOE STADI P, CuKa1), and c) LEED pattern of (001) surface of as-cleaved InTe sample, acquired at a primary electron energy of $58 \mathrm{eV}$

Samples for scanning tunnelling microscopy/spectroscopy (STM/STS) and AFM studies had a special $3 \times 4 \times 6 \mathrm{~mm}^{3}$ shape for cleavage in situ. InTe samples were cleaved by stainless tip in situ and just obtained (001) surface plane was studied by STM/STS/AFM. The last data were obtained by Omicron Nano Technology STM/AFM System operating with UHV better than $10^{-}$ 10 Torr at room temperature. The acquisition of STM data was conducted in the constant current mode. STS data were acquired in the current imaging tunneling spectroscopy (CITS) mode. AFM data were acquired in the constant force mode. Free software WS\&M v.4.0 from Nanotec Electronica was used while analyzing and processing the scanning probe data [13]. Thermal evaporator EFM-3 was applied for indium deposition in situ. Indium ion current inside the effusion cell was maintained to be constant during the indium deposition. The deposition rate was kept at approximately $0.07 \mathrm{ML} / \mathrm{min}$. Such rates allowed organizing activation-migration movement of deposited In with localization at the growth activation centers under subsequent annealing during 3-5 min up to $475 \mathrm{~K}$.

\section{RESULTS AND DISCUSSION}

\subsection{AFM and STM Study of InTe (001) Template}

Fig. 2 shows the results of AFM study of the initial InTe (001) surface obtained by cleavage in situ. 2D Fast Fourier Filtering (Fig. 2a) reveals a clear surface pattern corresponding to the InTe tetragonal crystal structure.

2D FFT filtering of the STM image shown in Fig. 2c also gives the same periodic surface structure. Fig. $2 \mathrm{~b}$ (AFM) and Fig. 2d (STM) show a periodicity of $\sim 8.45 \AA$ in the surface lattice of InTe (001) consistent with XRD data for a tetragonal crystal structure of the TlSe type. Thus, scanning probe studies of the InTe (001) surface obtained by cleavage confirm the lack of surface reconstruction, that is well known in the case of other layered indium chalcogenides [11, 12, 14, 15]. Finally, this makes it possible to conclude that InTe (001) crystal surface, especially that obtained by cleavage in situ, can act as a stable periodic template for the formation of nanostructures by the SSD method. 

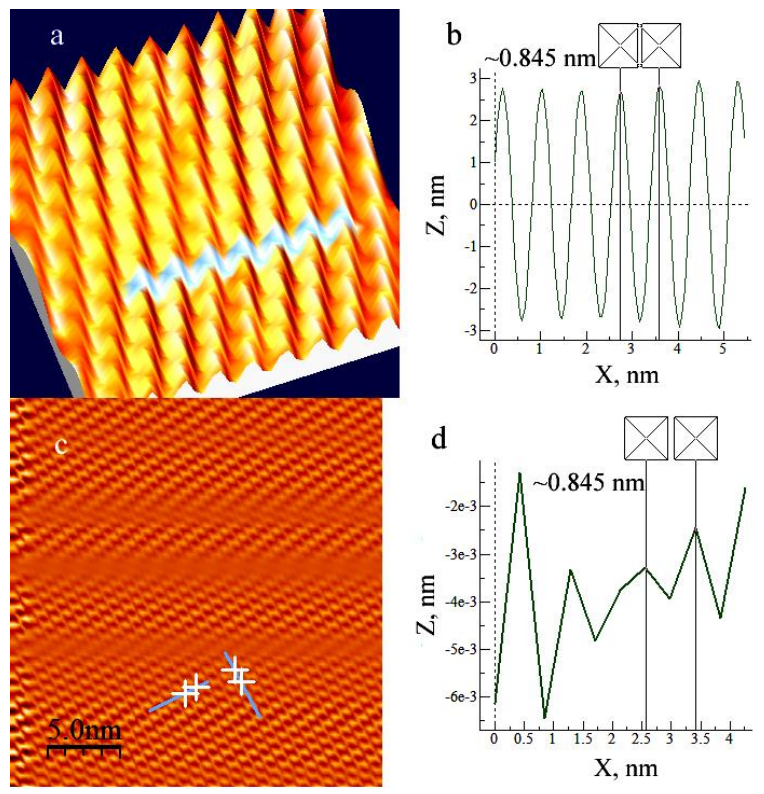

Fig. 2 - Study of the initial InTe (001) surface: AFM data - a) $3 \mathrm{D}$ visualization of a $2 \mathrm{D}$ FFT filtered $9.1 \times 9.2 \mathrm{~nm}^{2}$ image acquired at $0.459 \mathrm{nN}$ constant force mode with a subsequent topology profile shown in b); STM data - c) a 2D FFT filtered $24.8 \times 25.9 \mathrm{~nm}^{2}$ image (+ 1.6 bias, $59 \mathrm{pA}$ tunneling current) with a subsequent topology profile in $(\mathrm{d})$

\subsection{STM Study of InTe (001) Crystal Surface af- ter Indium Deposition and SSD Nanostruc- tures Formation}

On the other hand, STM study confirms the presence of a thermally activated migration mechanism for the formation of indium nanostructures after indium deposition on the surface of InTe by analyzing data on the distribution of pixel heights in STM images obtained under appropriate experimental conditions. Statistical analysis of the surface topography was conducted by Roughness Analysis tool in WSxM software.

Fig. 3 shows the corresponding histograms of the distribution of image pixel heights characteristic of the initial UHV cleavage, indium deposited surface and after subsequent annealing at different temperatures, respectively. In our case, the presented results are obtained for small degrees of indium coverage, thus providing a key role of the crystal surface as a template.

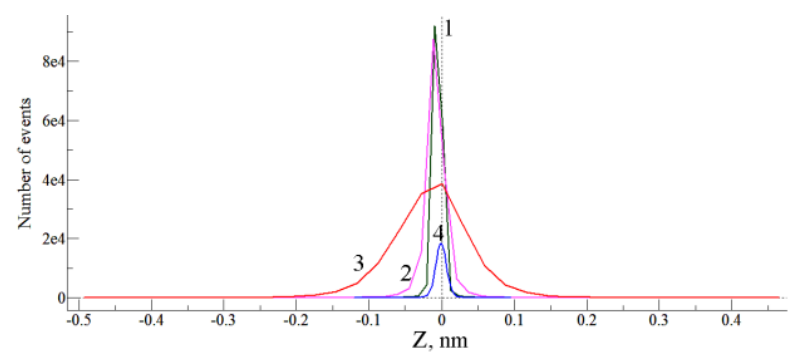

Fig. 3 - Distribution of pixel heights for $150 \times 150 \mathrm{~nm}^{2}$ STM images on the InTe (001) surface before (curve 1) and after In deposition: curve $2-5 \mathrm{~s}$ deposition, curve 3 - annealed at $125^{\circ} \mathrm{C}$, curve $4-$ annealed at $200{ }^{\circ} \mathrm{C}$

Fig. 3 shows a negligible redistribution of pixel heights immediately after indium deposition; however, heating of $\mathrm{In} / \mathrm{InTe}(001)$ system to a temperature of $125^{\circ} \mathrm{C}$, which is even lower than the melting point of indium, leads to migration of indium atoms with the formation of a more inhomogeneous surface structure. Heating of this system above the melting point of indium leads to the formation of a new surface with a relief similar to that of the initial InTe.

Moreover, other parameters that allow analyzing arrays of statistics on the surface relief, such as root mean square (RMS) roughness, skewness and kurtosis (excess) for In/InTe (001) system, the same as the data presented in Fig. 3, are collected in Table 1.

Table 1 - Comparison of $\mathrm{In} / \mathrm{InTe}(001)$ system parameters derived by roughness analysis tool

\begin{tabular}{|c|c|c|c|c|}
\hline $\begin{array}{c}\text { Surface } \\
\text { parameters }\end{array}$ & $\begin{array}{c}\text { Initial } \\
\text { InTe } \\
\text { template } \\
\text { state }\end{array}$ & $\begin{array}{c}\text { After In } \\
\text { deposition }\end{array}$ & $\begin{array}{c}\text { After } \\
\text { annealing } \\
\text { at } 125^{\circ} \mathrm{C}\end{array}$ & $\begin{array}{c}\text { After } \\
\text { annealing } \\
\text { at } 200{ }^{\circ} \mathrm{C}\end{array}$ \\
\hline RMS, nm & 0.0893 & 0.1793 & 0.0804 & 0.0885 \\
\hline Skewness & -0.0699 & 0.212 & 0.8043 & 0.1408 \\
\hline Kurtosis & 11.8652 & 9.2719 & 3.4145 & 3.3098 \\
\hline
\end{tabular}

The RMS roughness manifests itself in a greater inhomogeneity of surfaces after indium deposition (indium deposit "frozen" state) as compared to the initial InTe (001) template state. The value of the skewness (asymmetric parameter) indicates an increase in the asymmetric distribution of image pixel heights relative to the averaged plane (the distribution is symmetric with a parameter value equal to zero) for InTe surfaces after indium deposition and, especially, at the beginning of the thermally stimulated indium selforganizing process with a trend toward greater symmetry after SSD due to annealing of the samples. This is manifested when cells of the template relief are filled with indium due to its thermally activated migration. The simultaneous change in the kurtosis parameter also, most likely, indicates the filling of surface height irregularities due to the SSD process. It is known that kurtosis (surface acuity or peakness) for the Gaussian altitudinal distributions is close to the value of 3.0 [16]. Larger values for the initial InTe (001) template and slightly smaller values for templates directly deposited with indium indicate a narrower distribution of STM image pixel heights than for the annealed ones.

Since studies of the surface topology by scanning probe microscopy AFM/STM technique have shown that the surface of InTe crystal is not flat at the nanoscale, it is obvious that, as in the case of other layered indium chalcogenides $[11,12]$, for its pattern we could expect appropriate results of the formation of ordered nanostructures due to the SSD method application. We observed the formation of nanosized OD structures as a result of the SSD process arranged in an ordered manner. Fig. 4 shows STM data acquired from the InTe (001) surface after $95 \mathrm{~s}$ of In deposition subsequently annealed to $200{ }^{\circ} \mathrm{C}$. $2 \mathrm{D}$ FFT filtering of the raw STM image reveals the presence of periodic structures, the surface topology of which, when examined in detail (Fig. 4b), corresponds to the symmetry of the tetragonal lattice of indium telluride; however, the periodicity of these structures under appropriate experimental conditions is about $5 \mathrm{~nm}$.

It is easy to achieve geometric sizes of formed sur- 
face nanostructures which exceed the parameters of the surface lattice of the template [17] due to the GibbsThomson effect [18], which has a significant influence on the growth of nanostructures. During SSD-induced self-assembling, the smaller deposited particles of indium desorb more atoms than larger ones, which stops the growth of nanostructures from particles smaller than a certain critical radius.
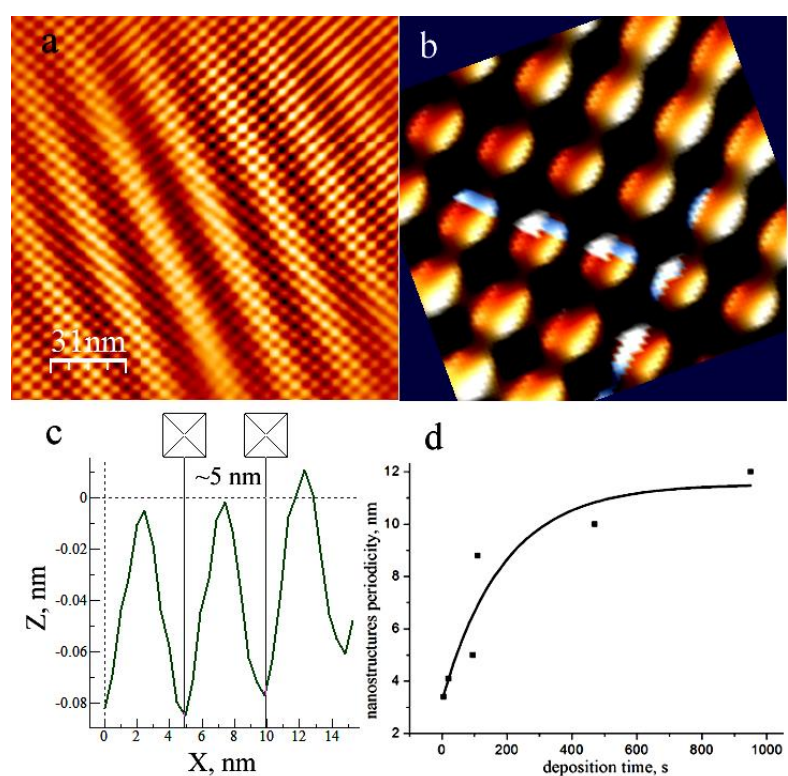

Fig. 4 - STM study of the In/InTe (001) nanosystem surface: a) 2 D FFT filtered $153.5 \times 153.5 \mathrm{~nm}^{2}$ image after $95 \mathrm{~s}$ of In deposition subsequently annealed at $200^{\circ} \mathrm{C},+1.6 \mathrm{~V}$ bias, $84 \mathrm{pA}$ tunneling current; b) 3D visualization zoomed fragment of (a) with subsequent topology profiling; c) profile with derived periodicity of $\sim 5 \mathrm{~nm}$ in the array of nanostructures; d) trend of selfassembled nanostructures periodicity via indium deposition time (squares show experimental STM derived data)

There are a number of studies on the influence of the degree of surface coverage of the template on the morphology of nanostructures obtained on the surface [19-22]. We were able to establish an exponential dependence of the kinetics of the increase in the periodicity of nanostructures formed on the template surface via the degree of indium deposited coverage followed by the SSD process. Fig. $4 \mathrm{~d}$ shows the curve obtained as a result of approximation of experimentally obtained values of surface indium nanostructures' periodicities due to the analysis of the corresponding topological profiles of STM images. As can be seen from Fig. 4d, the rapid expansion of the period of surface nanostructures occurs until the degree of indium coverage approaches a monolayer of deposited indium. It is obvious that in this case, the interaction of deposited indium with the template surface plays a predominant role for the formation of nano-structures in the SSD process, while in the case of higher degrees of indium coverage, nanostructures are formed under the influence of interactions in a thin layer of an indium film.

\subsection{STS Study of InTe (001) Template and In/InTe (001) Nanosystem}

Changes in the morphology of InTe (001) due to indium deposition are also clearly observed in STS data.
CITS mode that was used for STS data acquisition provides recording of the current-voltage $(C-V)$ curves for an array of pixels of a topographic STM image. The application of $C-V$ curves allows us to estimate the electronic energy structure of the studied surface both pointwise - in the place of the tunneling current, and locally - in a certain selected area. Fig. 5 shows normalized derivative $(d I / d V) /(I / V)$ curves via bias voltage between the probe and the studied surface averaged over $50 \times 50 \mathrm{~nm}^{2}$ area for the initial template (curve 1) and subsequent indium deposition (curves 2, 3, 4). Such differentiated and normalized dependences actually present the density of surface states (DOS) that participate in tunneling processes, in particular, near the top of the valence band (negative bias values) and the bottom of the conduction band (positive bias values) and the real width of the InTe energy gap. The averaging of local spectra over the investigated surface area allows to unambiguously interpret the changes in the DOS on the surface, which are associated with an increase in the degree of indium coverage.

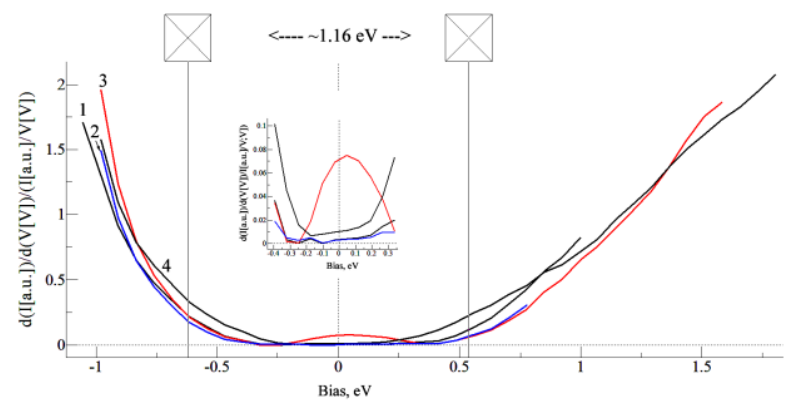

Fig. 5-STS data averaged over $50 \times 50 \mathrm{~nm}^{2}$ area on the InTe (001) surface: before In deposition - 1 (green curve); after In deposition: 2 (blue curve) $5 \mathrm{~s}, 3$ (red curve) $35 \mathrm{~s}, 4$ (black curve) $95 \mathrm{~s}$. The inset shows zoomed STS data within the band gap of InTe

It should be noted that the value of the InTe energy gap determined by STS from Fig. 5, curve 1, is consistent with previously reported data. It was reported that a bulk InTe crystal has a semiconductor optical band gap equal to $1.16 \mathrm{eV}$ [23]. Calculated structure characteristics and electronic and optical properties indicate that the InTe monolayer exhibits an indirect band gap of $1.286 \mathrm{eV}$ [24]. A sufficient DOS within InTe semiconductor band gap appears and grows with an increase in indium coverage (see Fig. 5, curve 3). With further growth of the indium coating (Fig. 5, curve 4), we obviously distinguish a relatively small number of local points of analysis with characteristic tunneling tip/semiconductor contact. In this case, the tunneling current probes the $\mathrm{In} / \mathrm{InTe}(001)$ nanostructure that is shown in curve 4 , which is manifested by narrowing energy gap to $0.5-0.6 \mathrm{eV}$. Indicative from this point of view is a zoomed fragment presented in Fig. 5 (the inset), which corresponds to the DOS distribution within biases' voltage range probing InTe energy gap. However, it should be noted that on the basis of such STS data it does not make sense to claim the formation of a continuous surface coating under specified deposition rates. The resolution for the obtained STS data was $80 \times 80$ analysis points regardless of the probed area size, i.e., in case of $50 \times 50 \mathrm{~nm}^{2}$ probed area, the discreteness of analysis points is equal to $6.25 \AA$. At the same time, it is 
well known that the tunneling current is collected from the surface area with a $1-2 \AA$ diameter only. Thus, the STS data obtained even for relatively small probing areas do not provide complete information on the phase state of the entire probed surface.

\section{CONCLUSIONS}

The (001) surface of a two-dimensional InTe layered semiconductor crystal was applied as a template for the directed assembly of indium nanostructures. We succeeded to organize the directed assembly process of metallic nanostructures for a given lattice texture of non-reconstructed InTe(001) surface obtained by cleavage in UHV. In fact, the templated solid-state dewetting approach led to the formation of deposited indium nanostructures, the shape and arrangement of

\section{REFERENCES}

1. Q. Zhao, R. Frisenda, T. Wang, A. Castellanos-Gomez, Nanoscale 11, 9845 (2019).

2. A. Politano, D. Campi, M. Cattelan, I. Ben Amara, S. Jaziri, A. Mazzotti, A. Barinov, B. Gürbulak, S. Duman, M. Agnoli, LS. Caputi, G. Granozzi, A. Cupolillo, Sci. Rep. 7, 3445 (2017).

3. J.H.C. Hogg, H.H. Sutherland, Acta Cryst. B 32, 2689 (1976).

4. F.L. Faita, C.S. Maduro de Campos, K. Ersching, P.S. Pizani, Mater. Chem. Phys. 125 No 1-2, 257 (2011).

5. M. Zapata-Torres, J.L. Peña, Y.P. Mascarenhas, R. CastroRodríguez, M. Meléndez-Lira, O. Calzadilla, Superficies y Vacío 13, 69 (2001).

6. Roughieh Rousina, G.K. Shivakumar, Crystal Res. Tech. 24 No 4, 475 (1989).

7. Z.R. Kudrynskyi, Z.D. Kovalyuk, V.M. Katerynchuk, R.L. Potsiluiko, J. Nano- Electron. Phys. 7 No 4, 04049 (2015).

8. C.V. Thompson, Ann. Rev. Mater. Res. 42 No 1, 399 (2012).

9. F. Leroy, L. Borowik, F. Cheynis et al, Surf. Sci. Rep. 71 No 2, 391 (2016).

10. R.A. Hughes, E. Menumerov, S. Neretina, Nanotechnology 28, 282002 (2017).

11. P.V. Galiy, P. Mazur, A. Ciszewski, T.M. Nenchuk, I.R. Yarovets', Eur. Phys. J. Plus 134, 70 (2019).

12. P.V. Galiy, T.M. Nenchuk, P. Mazur, A. Ciszewski, (2020).

13. I. Horcas, R. Fernandez, J.M. Gomez-Rodríguez, J. Colchero, Ya.M. Buzhuk, O.V. Tsvetkova, Appl. Nanosci. 10, 4629

which depend on the square surface lattice symmetry, as it could be obtained from bulk tetragonal InTe. We observed the formation of nanosized $0 \mathrm{D}$ structures as a result of the SSD process due to surface heating above the indium melting point. The STS spectra analysis showed good correlation between SSD and an increase in the amount of DOS within the semiconductor band gap of InTe corresponding to metallic phase with increasing degree of indium coverage.

In our opinion, the choice of experimental conditions which are successful for the formation of nano-structures, as shown, depends on the indium deposition rate and, consequently, on the degree of surface coating by deposit, as well as the choice of heating conditions to activate the dewetting process is another factor important for the successful formation of indium nanostructures on $2 \mathrm{D}$ surfaces of a layered InTe crystal.

J. Gomez-Herrero, A.M. Baro, Rev. Sci. Instrum. 78, 013705 (2007).

14. K. Fukutani, T. Sato, P.V. Galiy, K. Sugawara, T. Takahashi, Phys. Rev. B 93, 205156 (2016).

15. P.V. Galiy, P. Mazur, A. Ciszewski, T.M. Nenchuk, I.R. Yarovets, Ya.M. Buzhuk, O.R. Dveriy, J. Nano- Electron. Phys. 10 No 4, 04002 (2018).

16. M. Aguilar, A.I. Oliva, E. Anguiano, Surf. Sci. 420, 275 (1999).

17. P.V. Galiy, T.M. Nenchuk, P. Mazur, A. Ciszewski, I.R. Yarovets, J. Molec. Cryst. Liquid Cryst. 674 No 1, 11 (2018).

18. V.G. Dubrovskii, Nucleation Theory and Growth of Nanostructures (Springer-Verlag: Berlin Heidelberg: 2014).

19. Sudheer, Puspen Mondal, V.N. Rai, A.K. Srivastava, AIP Adv. 7, 075303 (2017).

20. A. Naseem, R.S. Muhammad, H. Muzamil, M.Z.M. Syed, S. Uzair, Mater. Res. Exp. 6, 116437 (2019).

21. I.K. El Zawawi, A.M. Manal, E.A. El-Sayad, J. Nanomater. 2017, 7509098 (2017).

22. Li Zeng, G. Yixin, Z. Fei, N. Chengqi, L. Hongkai, S. Jingyu, L. Xiaohui, J. Jinchun, Z. Shaohua, RCS Adv. 10, 16749 (2020).

23. H. Parlak, C. Erceleby, I. Gunal, H. Ozkan, N.M. Gasanly, Cryst. Res. Technol. 31, 673 (1996)

24. Y. Yujie Liao, H. Liu, G. Yuan, Z. Huang, X. Qi, Cryst. Res. Technol. 2000102 (2020).

\section{Формування наносистеми In/InTe методом вторинного твердотільного змочування}

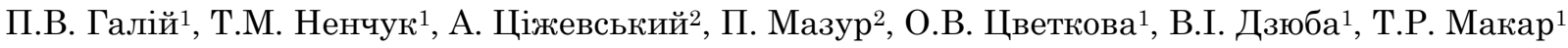 \\ 1 Львівський національний університет ілені Івана Франка, вул. Драголанова, 50, 79005 Львів, Україна \\ 2 Institute of Experimental Physics, University of Wroclaw, pl. Maxa Borna 9, 50-204 Wroclaw, Poland
}

\begin{abstract}
Для формування наносистеми In/InTe застосовано метод вторинного твердотільного змочування як перспективний спосіб отримання наноструктур. Фазово-елементний склад та структурна досконалість вихідної поверхні InTe характеризувались методами Х-променевої фротоелектронної спектроскопії, дифракції повільних електронів та атомно-силової мікроскопії. Методом дифракційного X-променевого структурного і фазового аналізів встановлено тетрагональну кристалічну структуру InTe типу TlSe (просторова група I4/mcm, параметри гратки $a=8,4414(6) \AA ⿻$, $c=7,1333(5) \AA$ ). Дослідження за допомогою скануючої тунельної мікроскопії вихідної поверхні InTe (001), як такої, що використовуеться як упорядкований шаблон після термічного осадження індію, показують, що фоома та розташування індукованих індієм наноструктур визначаються квадратною симетрією поверхневої гратки, що визначається тетрагональною об'ємною граткою InTe. Встановлено утворення нанорозмірних 0D-структур в результаті процесу вторинного твердотільного змочування внаслідок нагрівання поверхні вище температури плавлення індію. Скануюча тунельна спектроскопія виявляє кореляцію між кінетикою покриття індіем та збільшенням на поверхні InTe (001) величини густини станів у забороненій зоні InTe.
\end{abstract}

Ключові слова: Шаруваті халькогеніди, Самоорганізовані наноструктури, Вторинне твердотільне змочування, Скануючі тунельна мікроскопія/спектроскопія, Атомно-силова мікроскопія, Х-променева фотоелектронна спектроскопія, Дифракція повільних електронів. 